\title{
Integrated learning and project-based learning for project of electrical measurement and instrumentations in electrical engineering course
}

\author{
Natawee Chaijum ${ }^{1, *}$ Tiantada Hiranyachattada ${ }^{2}$ \\ 1,* Department of Electromechanic Manufacturing Engineering, Faculty of Engineering and Industrial Technology, \\ Bansomdejchaopraya Rajabhat University, Bangkok, Thailand \\ 2 Department of Animaton and Digital Media, Faculty of Science and Technology, Bansomdejchaopraya Rajabhat University, \\ Bangkok, Thailand
}

\begin{abstract}
:
Using integrated learning and project-based learning can make correlation of knowledge and skills in order to make students apply the knowledge to become a new knowledge for creating project to be prepared for Thailand 4.0 with the topic electrical measuring instrumentation project with the Internet of thing. The research process divided into 3 parts: 1) topics analysis and objectives analysis for integrated learning 2) project-based learning for projects assignment and 3) Integrated learning and project-based learning. The sample were $184^{\text {th }}$ year students in Electrical engineering manufacturing department, Bansomdejchaopraya Rajabhat University. The assessment stages were followed by 1) project proposal 2) project planning and design 3) project implementation 4) project evaluation and 5) project presentation and report. The result found that: students can create their electrical measuring instrumentation group's project from this learning method and the students' evaluation and feedback were agree with this learning model. In conclusion, leaning by using integrated learning and project-based learning can improve thinking skills, teamwork skills, use of technology and other skills related to their project topic such as microcontroller and computer programming also promoting students-centered and gives the opportunity to make discussion between students and lecturer to suggest and solve students problems.
\end{abstract}

Keywords: integrated learning, project-based learning, engineering project

\section{Introduction}

Due to Thailand has been facing lots of challenging problems such as, many of people living under the poverty, high level of inequality and living depend on the external technology (Puncreobutr, 2017). At present, Thailand was classified as a country driven by efficiency and classified as a middle income group. To developing the country in accordance with current situation need to develop in the field of research and development in technology and innovation (Office of the National Economic and Social Development Council, 2019). In 2016, Thai government announced Thailand 4.0 model which have focused on bringing the knowledge and updated technology to increase the ability, creating own technologies and innovation for driving the country to be free from the middle income trap to creating innovation requires knowledge, ability and creativity (Knowledge Management Institution, 2016). However, the important factor to make Thailand 4.0 success was to delivered the knowledge to the society because ecation is one of the important elements to improve the quality of human in order to be able to face the globalization and $21^{\text {st }}$ century era (Shidiq and Yamtinah, 2019). Education has a function to shape one's and to raise dignity. In addition, education can ensure a better life. As time goes by, it challenges a person to have a good education. However, a good education was only seen in its results beside the learning process (Gerhana, 2017) from this reason educating the people in Thai society must come from cooperation of the education in university by adapting learning model in classroom (Chularut, 2018 ; Tanjitanont and Junoysuwan, 2016). 
In learning model in education, the integrated learning is a learning model that combines two or more subjects to form a specific theme, integrated learning can enable students in learning, developing knowladge, thinking skills, social skills, and organizing skills (Fogarty, 1991) so the implementation of integrated learning can be increase students' literacy (Tsai et al., 2007) especially in engineering field which was an important field of national development. One of the efforts for the learning process which was predicted to be able to overcome these problems were through learning tools with the project-based learning model combined with the process skills approach. The process skills includes experimental skills, observing, measuring, and processing data (Jeenthong et al, 2014), classify, make hypothesis, control variables, make conclusions, implement, and communicate so this approach can support the implementation of the project- based learning model also project based learning model was a learning model that focuses on the activeness of students (Ergul and Kargin, 2014).

As problem mentioned, using integrated learning and project-based learning could correlation knowledge and skills together in order to make students apply the knowledge to become a new knowledge for creating project to be prepared for Thailand 4.0 (Wiboonyasake, 2018 ; Policy and Innovation Center, 2014 ; National Broadcasting and Telecommunication Commission, 2018). In this research bringing integrated learning and project-based learning for Electrical engineering course from the method mentioned to create an electrical measuring instrumentation project with the Internet of thing (IoT) technology as a guideline to create innovation for Thailand 4.0.

\section{Research methodology}

The research method for this research divided into 3 parts: 1) topics analysis and objectives analysis for integrated learning 2) project-based learning for projects assignment and 3) integrated learning and project-based learning.

\section{Topics analysis and objectives analysis for integrated learning}

In the first part, bringing 2 subjects integrated which were Principles of electronics subject and Electrical measurement and instrumentations subject for connecting the knowledge and concepts to create the necessary knowledge for students by way of selecting the most important and necessary topics for learning which focused on the apply existing knowledge, thinking skills, create creativity for improve learning outcome. In figure 1 shown the topics analysis method for integrated learning (Centre for Excellence in Learning and Teaching, 2017). Moreover, the other knowledge that related to students' project topic will be teaching too.

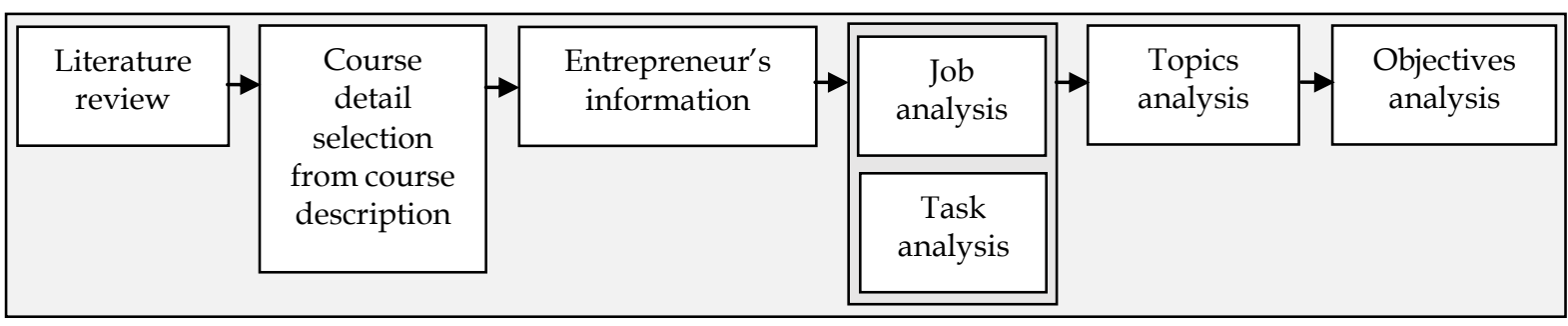

Figure 1. Topics analysis method

After analyse the topics from the above method to identify the sub-topics, objectives for integrated learning of both subjects, the result presented that in Principles of electronics subject, the topics was electronic devices the sub-topics were resistor, inductor, capacitor, diode, transistor, and integrated circuit. In Electrical measurement and instrumentations subjects the topic was voltage measurement the sub-topics were $\mathrm{DC}$ voltage measurement and $\mathrm{AC}$ voltage measurement, which were important topics and frequency used in the electrical engineering field. The objectives analysis of both subjects can be seen in table 1 and 2 . 
Table 1. Objectives analysis result of Principles of electronics subject

\begin{tabular}{cl}
\hline \multicolumn{1}{c}{ Sub-topics } & \multicolumn{1}{c}{ Objectives } \\
\hline Electronic devices & A1. Writing an electronic symbol \\
& A2. Electronic devices classification \\
& A3. Describe the electronic devices internal structure \\
& A4. Describe the electronic devices properties \\
& A5. Describe the advantages and disadvantages of electronic devices. \\
& A6. Connect the electronic devices in a circuits \\
A7. Calculate the electrical value in the electronic devices circuits
\end{tabular}

Note: electronic devices are resistor, inductor, capacitor, diode, transistor, and integrated circuit

Table 2. Objectives analysis result of Electrical measurement and instrumentations subject

\begin{tabular}{ll}
\hline \multicolumn{1}{c}{ Sub-topics } & \multicolumn{1}{c}{ Objectives } \\
\hline Voltage measurement & B1. Writing a voltmeter symbol \\
& B2. Connect the voltmeter in a circuits \\
& B3. Describe the electrical value formula of voltmeter. \\
& B4. Describe the advantages and disadvantages of voltmeter \\
& B5. Describe the voltmeter internal structure \\
B6. Describe the operation of the voltmeter & B7. Describe the method to increase multi-range voltage of voltmeter \\
B8. Calculate the electrical value from voltage measurement in a circuit & B9. Calculate and analyse the measurement error from voltage \\
measurement in a circuits
\end{tabular}

Project-based learning in electrical engineering course

In the second part, project-based learning emphasizes that students can be received experience while studying and gain various skills informed to Revised Bloom's Taxonomy which believed that exploration of problems from guiding of the lecturer to create their own projects to accept the challenges in the real world (Schuetz, 2018). The project-based learning and detail activities in sequences consist of the following stages: 1) finding topic and project proposal, 2) project planning and design, 3) monitoring project activities and implementation, 4) project evaluation and 5) project presentation and report. In electrical engineering course, the projects are first designed and selected based on the learning outcomes with the project briefs: 'Design and develop an Electrical measurement and instrumentations with IoT technology.

Integrated learning and project-based learning

In the third part, a combination between integrated learning and project-based learning. The integrated learning makes the students combine knowladge from 2 subjects and apply existing knowledge and thinking skills. While the project-based learning involves the student to active in discussion, make a plan and solve the problem according to Mioduser and Betzer (2008) represent that project-based learning improves the motivation, knowledge, skill, and the critical thinking. To use this integrated learning and project-based learning the implementation process for lecturer can be seen in figure 2 . 


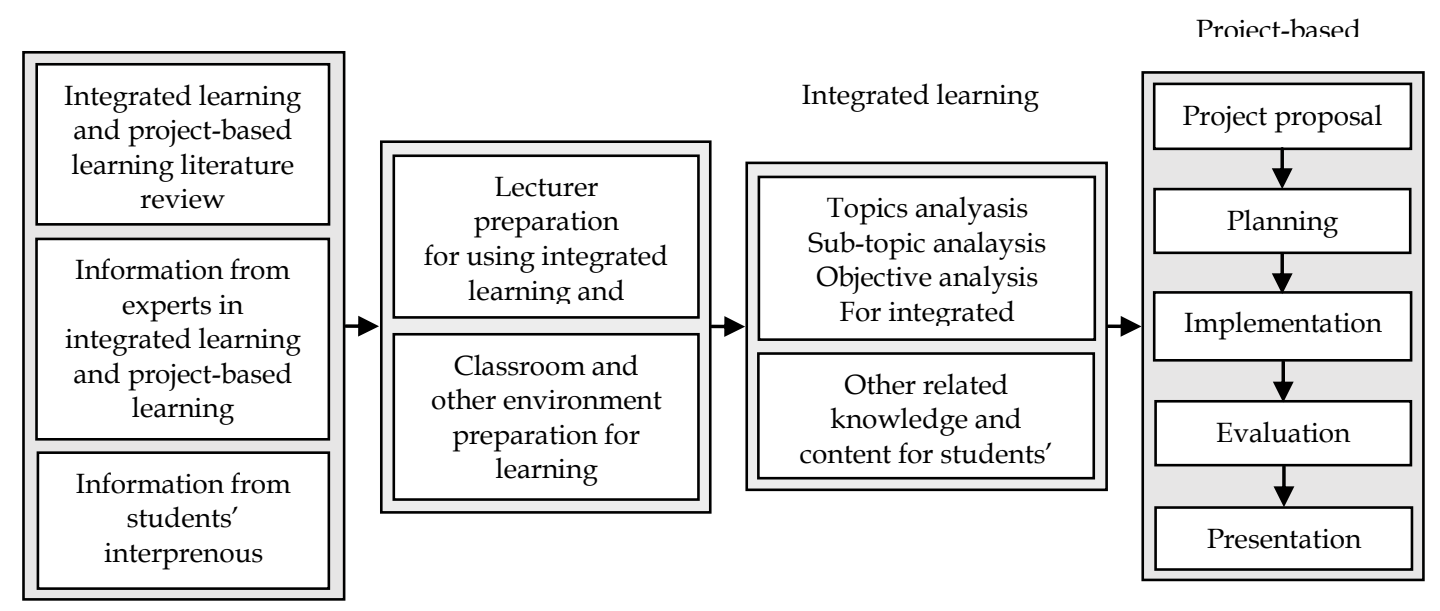

Figure 2. The integrated learning and project-based learning

\section{Result and Discussion}

From the research methodology and the integrated learning and project-based learning, the project will be given to students in group of three and students will select the group project's topic independently. The main tools used in the project was arduino microcontroller. The sample were 18 $4^{\text {th }}$ year students Department of Electromechanic Manufacturing Engineering, Faculty of Engineering and Industrial Technology, Bansomdejchaopraya Rajabhat University selected by purposive sampling method.

The result shown that students can create their group project and all the assessments were related to the students' project which follow the main stages of a project-based learning, the course assessment details (Shekar, 2014) and mean scores as shown in table 3 and students' project results as shown in figure 3.

Table 3. Course assessment details and students' score

\begin{tabular}{|c|c|c|}
\hline $\begin{array}{c}\text { Assessment stages } \\
\text { (Weight) }\end{array}$ & Details & $\begin{array}{l}\text { Mean score } \\
\text { (SD) }\end{array}$ \\
\hline 1. project proposal (20) & $\begin{array}{l}\text { - Group discussion, searching and analysing related } \\
\text { research to find the project topic from the identify } \\
\text { problems after learning by integrated learning } \\
\text { - Each group choose a project topic according to a } \\
\text { vote taken by the group after a discussion } \\
\text { - Students were presented with the topic needed for } \\
\text { preparing a project and project topic } \\
\text { - Lecturer suggestion about their project topic }\end{array}$ & $17.56(2.04)$ \\
\hline $\begin{array}{l}\text { 2. project planning and } \\
\text { design (20) }\end{array}$ & $\begin{array}{l}\text { - Each group design a timeline for project } \\
\text { components and set all the activities } \\
\text { - Lecturer suggest how to schedule their tasks and } \\
\text { direction for managing their time }\end{array}$ & $18.78(1.40)$ \\
\hline $\begin{array}{l}\text { 3. project implementation } \\
\text { (20) }\end{array}$ & $\begin{array}{l}\text { - Each group worked on the project for two months } \\
\text { - Lecturer suggestion and help students solve } \\
\text { problems they faced } \\
\text { - Lecturer monitor the students and the progress }\end{array}$ & $17.28(1.71)$ \\
\hline 4. project evaluation (20) & $\begin{array}{l}\text { - After the project was completed, all the students } \\
\text { met and conferred the project's result and }\end{array}$ & $15.56(1.15)$ \\
\hline
\end{tabular}




\begin{tabular}{llll}
\hline & $\begin{array}{l}\text { discussion with the lecturer } \\
\text { - Students received permission from lecturer to } \\
\text { show all the presentations }\end{array}$ & \\
\hline $\begin{array}{l}\text { 5. project presentation } \\
\text { and report (20) }\end{array}$ & $\begin{array}{l}\text { Each group presented what it had prepared for 15 } \\
\text { to } 20 \text { minutes, including the procedure used for } \\
\text { preparing the project and writing project report }\end{array}$ & 15.50 (1.04) \\
\hline
\end{tabular}

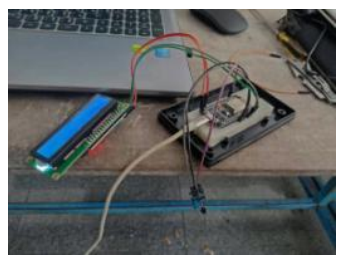

(a) Infrared IR Flame detector

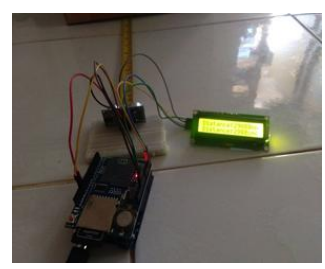

(d) Ultrasonic distance meter

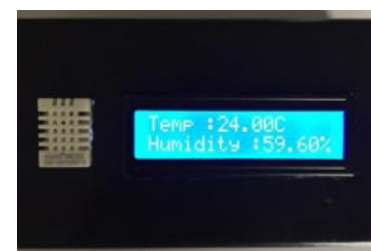

(b) Temperature Humidity Meter

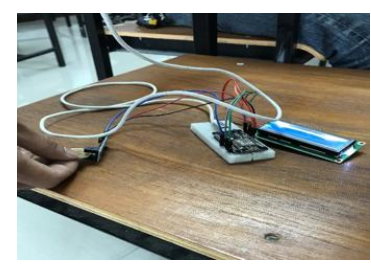

(e) Speedometer for counting coins

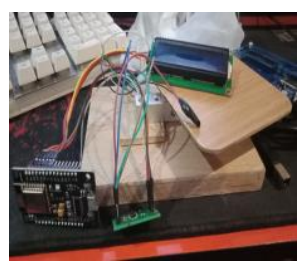

(c) Load cells censors scale

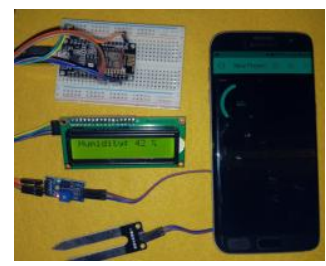

(f) Soil moisture meter

Figure 3. Students' project result

From the result of students' project, the lecturer found that: in project topic finding and project planning and design stages, most students did not understand how to search queries from the internet and unable to analyse the important objectives of the research so the lecturer suggest how to search for information using keywords and asked the student to write down a mind mapping in each group for presenting the idea in front of the class. In project implementation stage, students did not understand the meaning and writing of flowchart and block diagram so the lecturer explained and gave an examples moreover, students cannot connect the circuit correctly in some circuits of their project and some of the microcontroller program had bug so the lecturer show how to connects some circuits and help debugging the microcontroller program. Finally, in project evaluating and project presentation and report stages, students cannot explained or represent the result in term of table or graph also cannot discuss the results to conclude the experiment so the lecturer make the students to write mind mapping in each group with their experiment result to summarize and grouping the ideas.

Students' evaluation and feedback from integrated learning and project-based learning for subject of electrical measurement and instrumentations in electrical engineering course were agree that: the project contributed to their learning, students prefer the methodology of active learning, the project should be continued for the next semester and the projects helped students to develop various skills and knowledge which referencing to the research of Fregolentea et al. (2018). Finally, the lecturer must bring the problem and obstacle caused by the learning to improve the learning model for future research or work. 


\section{Conclusions}

In conclusion, this research represent the integrated learning and project-based learning, which improve scientific thinking, cooperative working skills, interpersonal communication, creativity, selfregulation, use of technology and other skills related to their research topic (Ravitz et al., 2012) such as microcontroller and computer programming also promoting students-centered and gives the opportunity of teamwork and discussion between students and lecturer especially engineering field. Moreover, it can also developing lecturers' pedagogical knowledge and improving students' selfregulation ability in learning and motivation, as well as changing their attitudes of learning (Kortam et al., 2018).

\section{Acknowledgements}

This research was supported by Research and Development Institute and Faculty of Engineering and industrial technology, Bansomdejchaopraya Rajabhat University, Bangkok, Thailand.

\section{References}

Center for Excellence in Learning and Teaching, (2017) "Revised Bloom's Taxonomy." http://www.celt.iastate.edu/teaching/effective-teaching-practices/revised-blooms-taxonomy (accessed January 2019)

Chularut P., (2018). Learning Management for Students in the Thailand 4.0 Era. Veridian e-journal silpakorn university. 11(2), 2363-2380

Ergul, N. R., and Kargın, E. K., (2014). The effect of project based learning on students' science success. Procedia-Social and Behavioral Sciences, 537-541.

Fogarty R., (1991). Ten Way to integrate curriculum. Journal Educational Leadership Integrating the Curriculum, 49(2), 61-65.

Fregolentea L. V., Henrique C. de A. Venturellia, Rodriguesa J., Erik M. da Silvab, Iuri S. Dinizb, Maria Regina W. Maciela., (2018). Project-Based Learning Applied to Distillation and Absorption Education: Integration Between Industry and a Chemical Engineering Undergraduate Course, CHEMICAL ENGINEERING TRANSACTIONS, 69, 427-432.

Gerhana, M., Mardiyana, M., \& Pramudya, I., (2017). The Effectiveness of Project Based Learning in Trigonometry. Journal Of Physics: Conference Series, 895, 012-027.

Jeenthong, T., Ruenwongsa, P., and Sriwattanarothai, N., (2014). Promoting integrated science process skills through betta-live science laboratory. Procedia-Social and Behavioral Sciences, 3292-3296.

Knowledge Management Institution., (2016). "Model thailand 4.0 drive to Stability, Prosperity and Sustainability." http://www.libarts.up.ac.th/v2/img/Thailand-4.0.pdf, (accessed January 2019)

Mioduser D. and Betzer N., (2008). The contribution of Project-based-learning to high-achievers' acquisition of technological knowledge and skills, International Journal of Technology and Design Education. 18(1). 59-77.

National Broadcasting and Telecommunication Commission, (2018) "Internet of Things Technology and Thailand 4.0 Policy." http://www.boi.go.th/upload/content/TIR_Newsletter_February2019_AW_5c908cc7bf8e5.pdf, (accessed February 2019)

Office of the National Economic and Social Development Council (NESDC), (2019) "Report on development of Thailand in 5 years results." https://www.nesdb.go.th/ewt_news.php?nid=8639\&filename=index, (accessed February 2019)

Policy and Innovation Center -PI., (2014) "Project-based Learning." http://pichet-pinit.in.th/wp content/uploads/2017/02/Final-Report-PjBL-Part-1.pdf, (accessed March 2019)

Puncreobutr V., (2017) “The policy drive of Thailand 4.0” http://www.stic.ac.th/ojs/index.php/sjhs/article/view/114/64, (accessed February 2019)

Ravitz, J., Hixson, N., English, M., \& Mergendoller, J., (2012) “Using project based learning to teach 21st century skills: Findings from a statewide initiative in Annual Meetings of the American Educational Research Association. Vancouver, BC." http://www. bie. org/research/study/PBL_21CS_WV, (accessed March 2019)

Shidiq, A., \& Yamtinah, S., (2019). Pre-service chemistry teachers' attitudes and attributes toward the twenty-first century skills. Journal Of Physics: Conference Series, 1157, 042014.

Shekar, A., (2014). Project based Learning in Engineering Design Education: Sharing Best Practices. 121 ${ }^{\text {st }}$ ASEE Annual Conference \& Exposition, Indianapolis, Indiana, 24.1016.1-24.1016.18.

Schuetz R., (2018) “Project-Based Learning: Benefits, Examples, and Resources. “ https://www.schoology.com/blog/projectbased-learning-pbl-benefits-examples-and-resources, (accessed March 2019)

Tanjitanont P. and Junoysuwan P., (2016). The Appropriate Model of Integrated Learning for Developing The New Generation of Graduates. RMUTP Research journal (special issue) in $5^{\text {th }}$ RMUTNC. 182-192.

Tsai C. C., Tuan H. L., Chin C. C. and Chang J. C., (2007). The design ideas of nested inquiry-based instruction model in Physical Science. Proceeding of the $2^{\text {nd }}$ NICE Symposium,

Wiboonyasake M., (2018) “Industry 4.0 VS Thailand 4.0.” https://www.aware.co.th/thailand4-0, (accessed March 2019) 